\title{
Exploring Different Written Corrective Feedback Preferences: Role of Learners' Mathmatical and Kinestetic Intelligence
}

\author{
Mehrdad Rashtchi ${ }^{1 *}$, Zulqarnain bin Abu Bakar ${ }^{2}$ \\ ${ }^{1}$ Department of Management and Humanities Universiti Teknologi PETRONAS, Seri Iskandar, \\ Perak Darul Ridzuan, Malaysia \\ ${ }^{2}$ Department of Management and Humanities Universiti Teknologi PETRONAS, Seri Iskandar, \\ Perak Darul Ridzuan, Malaysia \\ *Corresponding author
}

\begin{abstract}
Many research findings have shown that learners encounter many learning difficulties. However, for effective learning, one has to know oneself and having knowledge about one's strengths and weaknesses. The process of teaching and learning will be more effective and meaningful when teachers and learners know their potential, their unique styles, strengths and weaknesses in learning. Howard Gardner's theory of multiple intelligences is a psychological and educational theory espousing that eight types of "intelligence" exist in humans, each relating to a different sphere of human life and activity. This study aimed at exploring the preference of L2 learners towards different types of written corrective feedback and their relationship to learners' mathematical and kinesthetic intelligences. 50 L2 learners from Universiti Teknologi PETRONAS participated in the study. The results revealed that there is no significant difference between mathematically intelligent learners and kinesthetically intelligent ones regarding their preference towards written corrective feedback types.
\end{abstract}

Keywords: Written Corrective Feedback, Multiple Intelligences, Mathematical Intelligence, Kinesthetic Intelligence

\section{Introduction}

Error correction has been one of the important elements of L2 classrooms. According to Lightbown \& Spada (2013) corrective feedback is any indication of second language learners' non-L2-like use of an L2. Many studies have found corrective feedback to be generally beneficial to second language learning (Gass, 2003; Gass \& Selinker, 2001; Li, 2010). Therefore, there has been a growing interest in the role of corrective feedback within the realm of second language acquisition over the years and a number of researchers have studied its nature and role in second language learning/teaching (e.g., Doughty \& Varela, 1998; Lyster \& Ranta, 1997; Oliver, 2000).

Ellis (2009) identified five basic strategies for providing written corrective feedback: 1) Direct Corrective Feedback. It is when the learners are provided with the correct form. According to Ferris (2006), written corrective feedback can take different forms: inserting a missing morpheme or word, crossing out an unnecessary phrase, word or morpheme, and writing the correct form near or above the incorrect form. 2) Indirect Corrective Feedback. It involves indicating that the learner has made an error without actually correcting it. 3) Metalinguistic Corrective Feedback. In this type of feedback the instructor provides some kind of clue as to the nature of the error. 4) Electronic Feedback. In this type of feedback the teacher provides a hyperlink to a concordance file that provides examples of correct usage. 5) Reformulation. According to Ellis (2009: 98) "this type of feedback consists of a native 
speaker's reworking of the students' entire text to make the language seem as native-like as possible while keeping the content of the original intact".

During recent years, many SLA researchers have studied the relationship between MI theory, which according to Johnson (2007) recommends a model that confirms each individual's strength, talents, and skills, and the different aspects of L2 learning particularly writing skill. These studies have investigated the relationship between MI and the writing ability of L2 learners, the relationship between L2 learners' MI and their performance in writing and also the relationship between L2 learners' MI profile and their writing product (Sadeghi \& Farzizadeh, 2012; Ahmadian \& Hosseini, 2012; Marefat, 2007).

However, in spite of the growing number of studies investigating the relationship between MI profile of the learners and various elements related to their writing skills, less research, to the best of our current knowledge, is reported to explore the relationship between certain types of intelligences and different written corrective feedback types preferred by second language learners. Thus, to bridge the gap, this study was an attempt to find the (possible) relationship between second language learners' preferred written corrective feedback types and their mathematical and/or kinesthetic intelligences.

According to Gardner (1993: 9) bodily-kinesthetic intelligence is "the ability to solve problems or to fashion products using one's whole body, or parts of the body" and suggests dancers, athletes, surgeons and craftspeople as people who exhibit bodily-kinesthetic intelligence. Interestingly one aspect of learners who have dominant bodily-kinesthetic intelligence is the desire to "watch keenly" and the ability to "mimic". It is pointed out by Wright (2002: 87) that "the abilities to watch, observe keenly, imitate, and re-create are central to all performing arts. It is the capacity to involuntarily mimic and go through the experiences and feelings of others that allows us to understand and participate in the arts". Also, Gluck, Mercado, \& Myers (2007) believe that kinesthetical learning involves "direct demonstration".

Learners with dominant mathematical intelligence, however, are sensitive to logical patterns and relationships and they like to figure out logical puzzles (Armstrong, 2009). Describing the role of mathematical intelligence in language teaching contest, Morgan \& Fonseca (2004: 127) states that "in the language classroom problem-solving tasks are useful as learners focus mainly on meaning, but through constant rereading of the text to solve the problem, they acquire a familiarity with the vocabulary and structures used." Therefore, mathematical intelligence is connected with logical thinking and problem-solving abilities in order to find the correct form of the language. Moreover, in terms of second or foreign language learning, learners with dominant mathematical intelligence "can sequence described events in chronological order, classify language items easily, or successfully manage to work on problem-solving activities" (Spirovska, 2013: 11).

As mentioned earlier, this study aims to investigate any (possible) relationship between second language learners' preferred written corrective feedback types and their mathematical and kinesthetic intelligences. However, it did not investigate different extraneous variables (i.e., gender, age, proficiency level, and sociocultural backgrounds) and sought to answer the following questions:

Is there any significant relationship between learners' mathematical or kinesthetic intelligences and their preferred written corrective feedback type? 


\section{Methodology}

\subsection{Participants}

This study involved 50 participants from foundation program students in Universiti Teknologi PETRONAS. These learners attended English writing courses for 3 hours per week. The course mainly concentrates on writing skills including the ability to develop the various ideas but the classes also include work on the formal aspects of language including grammar. These students have successfully completed their SPM, O-Level or equivalent. Generally, this program is to prepare them for admission into UTP degree programs. As an entry requirement to this program, students should pass SPM/ SPMV (or O-level equivalent) with grade $\mathrm{C}$ in some subjects including English language. Therefore, students were proficient enough in reading and writing English to understand the questionnaire items and to provide reliable responses. Moreover, the first dominant intelligent of these participants is either mathematical or kinesthetic intelligence.

\subsection{Instruments}

Two instruments were employed: first a multiple intelligence test to which a number of randomly chosen foundation program students in Universiti Teknologi PETRONAS answered to determine their MI profile and identify their first dominant intelligence. This test was the Multiple Intelligences for Adult Literacy and Education developed in 1991 by Leslie Shelton, Joan Sheldon Conan, and Holly Fulghum-Nutters, and it was funded by the California State Library Foundation. Also, for the convenience of the researcher as well as participants the online version of this test was used.

The second instrument was a preference questionnaire. All of the questionnaire items were based on items from questionnaires used in previous studies that examined similar research questions (Ferris, 1995; Leki, 1991; Saito, 1994; Amrhein \& Nassaji, 2010), which increased the validity of the research tool. The adopted questionnaire was developed based on a 5-point Likert-type format, ranging from 1 (not useful at all) to 5 (very useful), and the major aim of which was to investigate the participants' preferred types of corrective feedback in their written assignments. The internal consistency of the adopted questionnaire was also estimated through running Cronbach's alpha. The results indicated that the Cronbach's alpha value for the instrument was .71 that, according to DeVellis (2011), a Cronbach's alpha coefficient above .7 is preferable.

\subsection{Procedure}

First the MI test was administered to a randomly selected group of participants within a week to identify a group of students with dominant mathematical or kinesthetic intelligence. The random selection of participants and administration of MI test was done to the point that we identified 25 students with mathematical intelligence as their first dominant one and 25 kinesthetically intelligent students.

After recognizing 50 students who were mathematically or kinesthetically intelligent, the preference questionnaire was given out to them to know about their written corrective feedback types preferences. Moreover, the researcher was present during the session for further explanations regarding the items in the questionnaire to eschew the occurrence of any possible misunderstanding on the part of the participants. 


\subsection{Result and Discussion}

In order to address the research question the preference questionnaire responses of both groups of learners (mathematically intelligent and kinesthetically intelligent) were recorded in an excel spreadsheet and then imported to SPSS 23.0 for statistical analysis. For the quantitative data from the Likert scale items, the mean value of responses to each type of written corrective feedback were calculated. Also, Paired Sample T-Test was used in order to determine if there was any significant difference among the two groups of students regarding their preference towards a particular written corrective feedback.

The items in the questionnaire examined participants' opinions of the usefulness of different types of written corrective feedback. The types of written corrective feedback were represented by an example of each and participants rated them $(1=$ not useful at all, $2=$ not useful, 3 = doesn't matter, 4 = quite useful, and $5=$ very useful). Table 1 shows the two groups of students' mean ratings for each type of written corrective feedback.

Table 1: Students' Mean Ratings for Each Type of Written Corrective Feedback

\begin{tabular}{|l|l|l|}
\hline \multicolumn{1}{|c|}{ Written Corrective Feedback Type } & $\begin{array}{c}\text { Mean Value of the Responses by } \\
\text { Students with Dominant } \\
\text { Mathematical Intelligence }\end{array}$ & $\begin{array}{l}\text { Mean Value of the Responses } \\
\text { by Students with Dominant } \\
\text { Kinesthetic Intelligence }\end{array}$ \\
\hline Clues or directions on how to fix an error & 3.3000 & 3.0400 \\
\hline Error correction with a comment & 4.3000 & 4.3000 \\
\hline Error Identification & 2.2000 & 2.2200 \\
\hline Comment with no correction & 3.2600 & 3.1000 \\
\hline Correction with no comment & 3.8400 & 3.7800 \\
\hline
\end{tabular}

For "clues or directions on how to fix an error" (e.g., direction to a certain section of a grammar book, dictionary, or class worksheet), the mean response from mathematically intelligent students as well as kinesthetically intelligent students (3.30) and (3.04) respectively demonstrate an overall neutral rating. For "error correction with a comment", the mean responses from both groups (4.30) demonstrate overall positive rating. For "error identification", the mean responses from the students with dominant mathematical intelligence (2.2) and the students with dominant kinesthetic intelligence (2.22) demonstrate an overall negative rating. For "comment with no correction", the mean response from mathematically intelligent students as well as kinesthetically intelligent students (3.26) and (3.1) respectively demonstrate an overall neutral rating and also for "correction with no comment", the mean responses from the students with dominant mathematical intelligence (3.84) and kinesthetically intelligent students (3.78) demonstrate an overall neutral to positive rating.

Having obtained the preference trend among both groups of students, in order to find the any significant difference between these two groups responses to the preference survey, Paired t-test was utilized. Tables 2 to 6 summarize the comparison between the mean responses of mathematically intelligent and the kinesthetically intelligent students to the preference survey of the written corrective feedback types. 
Table 2: Comparison of the Mean Responses to the Preference Questionnaire for "Clues or directions on how to fix an error" by Both Groups of Students

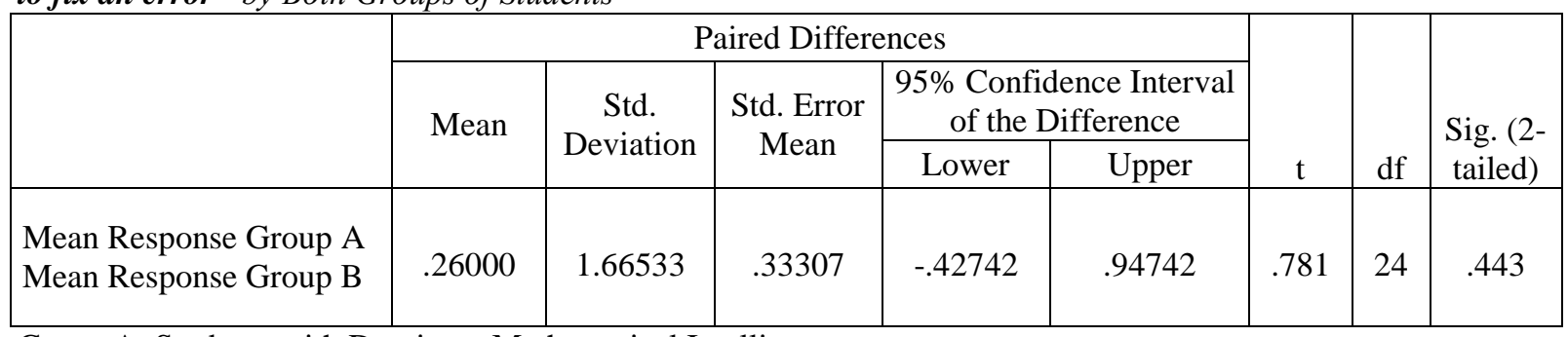

Group A: Students with Dominant Mathematical Intelligence

Group B: Students with Dominant Kinesthetic Intelligence

Table 3: Comparison of the Mean Responses to the Preference Questionnaire for "Error correction with a comment" by Both Groups of Students

\begin{tabular}{|c|c|c|c|c|c|c|c|c|}
\hline & & & aired Differ & nces & & & & \\
\hline & Mean & Std. & Std. Error & $\begin{array}{r}95 \% \text { Con } \\
\text { of the }\end{array}$ & $\begin{array}{l}\text { ce Interval } \\
\text { erence }\end{array}$ & & & Sig. (2 \\
\hline & & & & Lower & Upper & $\mathrm{t}$ & df & tailed) \\
\hline $\begin{array}{l}\text { Mean Response Group A } \\
\text { Mean Response Group B }\end{array}$ & .00000 & 1.27475 & .25495 & -.52619 & .52619 & .000 & 24 & 1.000 \\
\hline
\end{tabular}

Group A: Students with Dominant Mathematical Intelligence

Group B: Students with Dominant Kinesthetic Intelligence

Table 4: Comparison of the Mean Responses to the Preference Questionnaire for "Error Identification" by Both Groups of Students

\begin{tabular}{|c|c|c|c|c|c|c|c|c|}
\hline & \multicolumn{5}{|c|}{ Paired Differences } & \multirow[b]{3}{*}{$\mathrm{t}$} & \multirow[b]{3}{*}{ df } & \multirow{3}{*}{$\begin{array}{l}\text { Sig. (2- } \\
\text { tailed) }\end{array}$} \\
\hline & \multirow[t]{2}{*}{ Mean } & \multirow{2}{*}{$\begin{array}{c}\text { Std. } \\
\text { Deviation }\end{array}$} & \multirow{2}{*}{$\begin{array}{l}\text { Std. Error } \\
\text { Mean }\end{array}$} & \multicolumn{2}{|c|}{$\begin{array}{l}95 \% \text { Confidence Interval } \\
\text { of the Difference }\end{array}$} & & & \\
\hline & & & & Lower & Upper & & & \\
\hline $\begin{array}{l}\text { Mean Response Group A } \\
\text { Mean Response Group B }\end{array}$ & .02000 & 1.40297 & .28059 & -.59912 & .55912 & .071 & 24 & .944 \\
\hline
\end{tabular}

Group A: Students with Dominant Mathematical Intelligence

Group B: Students with Dominant Kinesthetic Intelligence

Table 5: Comparison of the Mean Responses to the Preference Questionnaire for "Comment with no correction" by Both Groups of Students

\begin{tabular}{|c|c|c|c|c|c|c|c|c|}
\hline & \multicolumn{5}{|c|}{ Paired Differences } & \multirow[b]{3}{*}{$\mathrm{t}$} & \multirow[b]{3}{*}{ df } & \multirow{3}{*}{$\begin{array}{l}\text { Sig. (2- } \\
\text { tailed) }\end{array}$} \\
\hline & \multirow{2}{*}{ Mean } & \multirow{2}{*}{$\begin{array}{c}\text { Std. } \\
\text { Deviation }\end{array}$} & \multirow{2}{*}{$\begin{array}{l}\text { Std. Error } \\
\text { Mean }\end{array}$} & \multicolumn{2}{|c|}{$\begin{array}{l}95 \% \text { Confidence Interval } \\
\text { of the Difference }\end{array}$} & & & \\
\hline & & & & Lower & Upper & & & \\
\hline $\begin{array}{l}\text { Mean Response Group A } \\
\text { Mean Response Group B }\end{array}$ & .16000 & 1.53921 & .30784 & -.47535 & .79535 & .520 & 24 & .608 \\
\hline
\end{tabular}

Group A: Students with Dominant Mathematical Intelligence

Group B: Students with Dominant Kinesthetic Intelligence

Table 6: Comparison of the Mean Responses to the Preference Questionnaire for "Correction with no comment" by Both Groups of Students

\begin{tabular}{|l|l|l|l|} 
Paired Differences & $\mathrm{t}$ & $\mathrm{df}$ & Sig. (2- \\
\hline
\end{tabular}




\begin{tabular}{|l|c|c|c|c|c|c|c|c|}
\hline & \multirow{2}{*}{ Mean } & \multirow{2}{*}{$\begin{array}{c}\text { Std. } \\
\text { Deviation }\end{array}$} & \multirow{2}{*}{$\begin{array}{c}\text { Std. Error } \\
\text { Mean }\end{array}$} & $\begin{array}{c}\text { 95\% Confidence Interval } \\
\text { of the Difference }\end{array}$ & & \multirow{2}{*}{ tailed) } \\
\cline { 5 - 6 } & & & & Lower & Upper & & & \\
\hline $\begin{array}{l}\text { Mean Response Group A } \\
\text { Mean Response Group B }\end{array}$ & .06000 & 1.03401 & .20680 & -.63682 & .48682 & .290 & 24 & .774 \\
\hline
\end{tabular}

Group A: Students with Dominant Mathematical Intelligence

Group B: Students with Dominant Kinesthetic Intelligence

As the tables above show, there is no significant relationship between the preference of mathematically intelligent students and the kinesthetically intelligent ones regarding the written corrective feedback types. Since the value of Significance (Sig.) shown in the table is more than the p-value $(\alpha=0.05)$, there is a 95 percent confidence in the claim that there is no significant relationship between the preference of two groups of students who participated in this study.

\section{Conclusion}

Although this study failed to establish a relationship between MI profile of the learners and their preference towards a certain written corrective feedback type, MI theory still plays an important role in educational reform in which students with different intelligence types and diverse intellectual abilities can benefit more from different educational methods that are designed for their individual needs and capabilities (Sadeghi \& Farzizadeh, 2012).

Moreover, there are a few limitations to this study which might have influenced the current results. First, this study should be replicated with larger samples while controlling the effect of some minor variables such as age, gender and sociocultural background because an accurate study of relationships that are investigated in the current research requires adequate replication, extensive research and careful control of minor variables. Consequently, a limited number of such studies are not enough and further research should be taken into consideration. Furthermore, the participants in this study did not have the chance to be exposed to different types of feedback for extended period of time and did not experience all these types of feedback in their written assignments and they were just exposed to the samples of different types of feedback while answering the survey questions.

Finally, despite the fact that the current study did not find any significant and clear trend between the preference of different group of learners and their MI profile, it should be emphasized that Gardner's (1983) MI theory has educational implications through which each learner's specific intelligence types enable the teacher to adapt his/her teaching styles to the intelligences and learning preferences that inform individual learners. Therefore, further exploration into the growing and complicated potentials of multiple intelligences needs to be carried out. 


\section{References}

Ahmadian, M., \& Hosseini, S. (2012). A Study of the Relationship Between Iranian EFL Learners' Multiple Intelligences and their Performance on Writing. Mediterranean Journal of Social Sciences, 3(1), 111-126.

Amrhein, H., \& Nassaji, H. (2010). Written corrective feedback: What do students and teachers prefer and why? . Canadian Journal of Applied Linguistics, 13, 95-127.

Armstrong, T. (2009). Multiple Intelligences in the Classroom. Alexandria, Virginia, USA: Association for Supervision and Curriculum Development.

DeVellis , R. (2011). Scale Development: Theory and Applications. Thousand Oaks, California, USA: SAGE Publications.

Doughty, C., \& Varela, E. (1998). Communicative focus on form. In C. Doughty, \& J. Williams (Eds.), Focus on form in classroom second language acquisition (pp. 114-138). New York: Cambridge University Press.

Ellis, R. (2009). A typology of written corrective feedback types. ELT Journal, 63(2), 97-107.

Ferris, D. (1995). Student Reactions to Teacher Response in Multiple-Draft Composition Classrooms. TESOL Quarterly, 29(1), 33-53.

Ferris, D. (2006). Does error feedback help student writers? New evidence on the short- and long-term effects of written error correction. In K. Hyland, \& F. Hyland (Eds.), Feedback in Second Language Writing: Contexts and Issues. (pp. 81-104). Cambridge: Cambridge University Press.

Gardner, H. E. (1993). Multiple Intelligences: the theory in practice. USA: Basic Books.

Gass, S. (2003). Input and Interaction. In C. J. Doughty, \& M. H. Long (Eds.), The Handbook of Second Language Acquisition (pp. 224-255). Malden, Massachusetts: Blackwell Publishing.

Gass, S. M., \& Selinker, L. (2001). Second Language Acquisition: An Introductory Course. Mahwah, New Jersey: Lawrence Erlbaum Associates.

Gluck, M., Mercado, E., \& Myers , C. (2007). Learning and Memory: From Brain to Behavior. New York: Worth Publishers.

Johnson, M. (2007). The Effect of Multiple Intelligences on Elementary Student Performance. Dominican University of California, School of Education, San Rafael.

Leki, I. (1991). The Preferences of ESL Students for Error Correction in College-Level Writing Classes. Foreign Language Annals, 24(3), 203-218.

Li, S. (2010). The effectiveness of corrective feedback in SLA: A meta-analysis. Language Learning, 60(2), 309-365.

Lightbown, P. M., \& Spada, N. (2013). How Languages are Learned. Oxford: Oxford University Press.

Lyster, R., \& Ranta, L. (1997). CORRECTIVE FEEDBACK AND LEARNER UPTAKE: Negotiation of Form in Communicative Classrooms. Studies in Second Language Acquisition, 19(1), 37-66.

Marefat, F. (2007). Multiple intelligences: Voices from an EFL writing class. Pazhuhesh-e Zabanha-ye Khareji, 32(S), 145-162. 
Morgan, J. A., \& Fonseca, C. (2004). Multiple Intelligence Theory and Foreign Language Learning: A Brain-based Perspective. International Journal of English Studies, 4(1), 119136.

Oliver, R. (2000). Age Differences in Negotiation and Feedback in Classroom and Pairwork. Language Learning, 50(1), 119-151.

Sadeghi, K., \& Farzizadeh, B. (2012 ). The Relationship between Multiple Intelligences and Writing Ability of Iranian EFL Learners. English Language Teaching, 5(11), 136-142.

Saito, H. (1994). Teachers' Practices and Students' Preferences for Feedback on Second Language Writing: A Case Study of Adult ESL Learners. TESL Canada Journal, 11(2), 46-70.

Spirovska, E. (2013). Integrating Multiple Intelligences in Teaching English as a Foreign Language - Seeu Experiences and Practices. SEEU Review, 9(1), 9-20.

Wright, S. (2002). The Arts, Young Children, and Learning. Pearson. 